International Business and Global Economy 2018, no. 37, pp. 198-211

Biznes międzynarodowy w gospodarce globalnej 2018, nr 37, s. 198-211

Edited by the Institute of International Business, University of Gdańsk

ISSN 2300-6102

e-ISSN 2353-9496

DOI 10.4467/23539496IB.18.014.9387

Monika Wojtas

Uniwersytet Marii Curie-Skłodowskiej w Lublinie

\title{
Tendencje protekcjonistyczne w handlu światowym
}

Przedmiotem artykułu jest ocena rozwoju tendencji protekcjonistycznych w gospodarce światowej po kryzysie gospodarczym 2008-2009. Naturalną prawidłowością jest wzrost działań protekcjonistycznych $\mathrm{w}$ okresach kryzysów. W pracy przedstawiono stosowanie barier tradycyjnych (nakładanych przy przekraczaniu przez towar granicy celnej) oraz współczesnych barier o charakterze regulacyjnym (wynikających z wewnętrznej polityki gospodarczej krajów). Analiza obejmuje bariery nakładane w latach 2009-2017. Jako specyficzne przejawy protekcjonizmu wskazano także brak postępów w multilateralnych negocjacjach handlowych prowadzonych na forum Światowej Organizacji Handlu oraz spadek zainteresowania zawieraniem regionalnych porozumień handlowych. Ocena wpływu protekcjonistycznych narzędzi nie jest jednoznaczna, widać jednak stopniowy wzrost zainteresowania protekcjonizmem, zwłaszcza w latach 2015-2017. Częściej także wprowadza się bariery o charakterze pozataryfowym - subsydia, środki ochronne i wymogi składnika krajowego.

Słowa kluczowe: polityka handlowa, protekcjonizm, cła, instrumenty pozataryfowe

Klasyfikacja JEL: F13, F10, F68, G01

\section{Protectionist tendencies in world trade}

The aim of the paper is to evaluate the proliferation of protectionist policies after the economic crisis of 2008-2009. The spread of protectionism is to be expected in times of recession. The paper presents the use of both traditional trade barriers (tariffs and other border measures) as well as regulatory barriers (behind-the-border measures) in 2009-2017. The lack of progress in multilateral trade negotiations and stagnation in the development of regional trade agreements are also indicated as specific manifestations of a protectionist approach to trade policy. The impact of protectionism on trade seems vague, but what is obvious is a gradual increase in protectionism, in particular during the past 3 years. This is accompanied by a spreading of non-tariff barriers, in particular subsidies (export and domestic), trade remedies, and localization requirements.

Keywords: trade policy, protectionism, tariffs, non-tariff barriers

JEL classification: F13, F10, F68, G01 


\section{Wprowadzenie}

Kryzys finansowy, który wybuchł w Stanach Zjednoczonych w 2008 r., $\mathrm{w}$ szybkim tempie przerodził się $\mathrm{w}$ załamanie gospodarcze i rozprzestrzenił na wszystkie kraje świata. Jego przejawem był spadek tempa wzrostu światowego produktu oraz największe od czasów II wojny światowej załamanie obrotów w handlu międzynarodowym. Wartość światowego eksportu w 2009 r. spadła o 22,25\% , załamanie było jednak krótkotrwałe i stopa wzrostu w latach 2010 i 2011 wynosiła odpowiednio 21,9 i 19,9\%. Od 2012 r. tempo wzrostu światowego eksportu było zdecydowanie niższe. Średnia stopa wzrostu w latach 2012-2014 wyniosła 1,18\%, natomiast w latach 2015 i 2016 zanotowano spadek, który wynosił odpowiednio - $12,87 \%$ oraz $-3,05 \%$ (rys. 1). Spadek wartości eksportu można w dużej mierze wytłumaczyć spadkiem cen surowców oraz zmianami kursów walut [Wojtas, 2017; Białowąs, 2017]. Jednak także analiza w ujęciu wolumenowym ujawnia negatywne tendencje $w$ handlu. W latach 2012-2015 średni roczny wzrost eksportu wynosił 3,3\% , a więc niewiele więcej niż średnie roczne tempo wzrostu PKB [Jean, 2017].

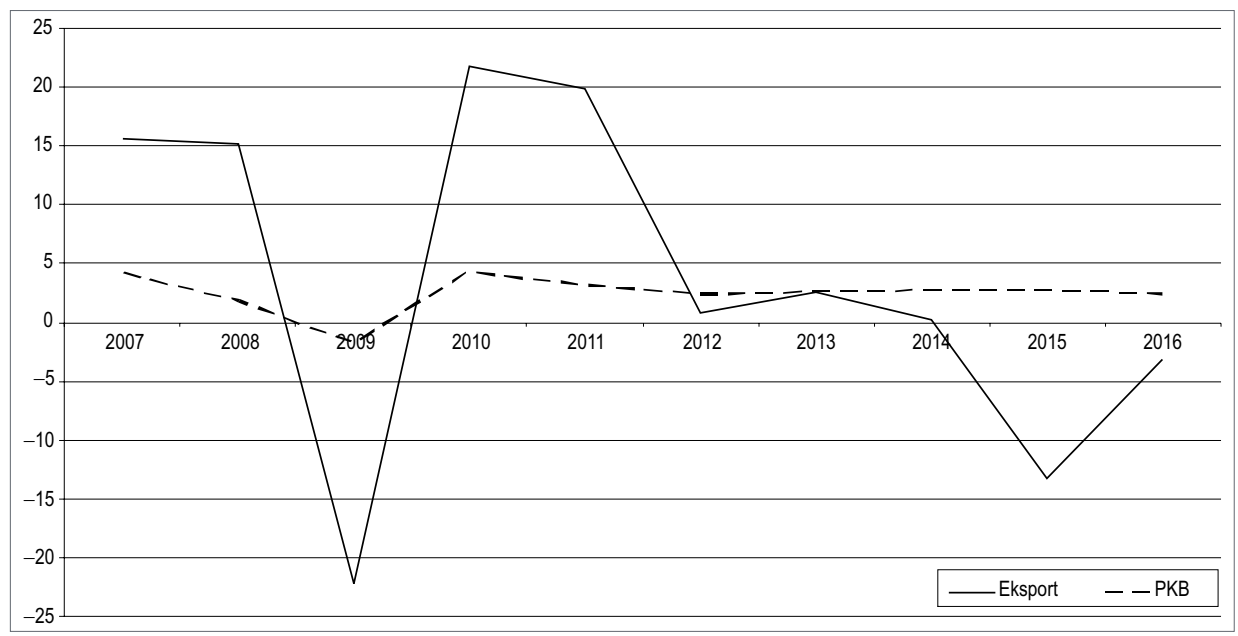

Rysunek 1. Tempo wzrostu światowego PKB i światowego eksportu w latach 2007-2016 $(\mathrm{w} \%)$

Źródło: [UNCTAD, 2018].

Załamanie obrotów handlowych w czasie kryzysu było głębsze niż spadek światowego PKB. Poza krótkotrwałą poprawą sytuacji w latach 2010-2011 tempo wzrostu eksportu od 2012 r. utrzymuje się na niskim poziomie i pozostaje niższe niż tempo wzrostu światowego PKB. Powstało wiele opracowań próbujących wy- 
jaśnić przyczyny tak głębokiego załamania handlu w 2009 r., a także stagnacji stóp wzrostu handlu od 2012 r. [Constantinescu, Mattoo, Ruta, 2015; Hoekman, 2015; ECB, 2016; Ollivaud, Schwellnus, 2015]. Wymieniano m.in. nasilenie się protekcjonizmu handlowego oraz spowolnienie procesu liberalizacji wymiany na świecie. Już na początku kryzysu pojawiły się ostrzeżenia dotyczące groźby powtórzenia się sytuacji z czasów Wielkiego Kryzysu i wprowadzenia przez Stany Zjednoczone tzw. taryfy Smoota-Hawleya, która doprowadziła do eskalacji taryf celnych i przyczyniła się do pogłębienia kryzysu [Eichengreen, 2008], rozpoczęto także monitorowanie zmian w polityce handlowej.

Celem opracowania jest ocena protekcjonistycznych tendencji $\mathrm{w}$ polityce handlowej na świecie po kryzysie gospodarczym lat 2008-2009. Przedmiotem analizy są bariery wprowadzane w latach 2009-2017. Uwzględnione zostały zarówno tradycyjne bariery handlowe, jak i bariery o charakterze regulacyjnym, których znaczenie w ostatnich latach wzrasta. Jako specyficzne przejawy protekcjonizmu wskazano także brak postępów w multilateralnych negocjacjach handlowych prowadzonych na forum Światowej Organizacji Handlu oraz spadek zainteresowania zawieraniem regionalnych porozumień handlowych.

\section{Analiza barier handlowych stosowanych w latach 2009-2017}

Współczesny protekcjonizm, a zwłaszcza instrumenty stosowane od ostatniego kryzysu, przybierały różne formy. Należały do nich zarówno instrumenty nakładane przy przekraczaniu przez towary granicy celnej kraju (tzw. border measures), do których zaliczamy przede wszystkim cła, ale także bariery o charakterze regulacyjnym, wynikające z wewnętrznych przepisów poszczególnych krajów (tzw. behind-the-boder measures). Wśród stosowanych narzędzi oprócz podwyższania stawek celnych wymienia się politykę proeksportową, politykę Buy National (,,kupuj krajowe"), pakiety ratunkowe czy subsydiowanie krajowych producentów. W efekcie zmierzenie poziomu protekcjonizmu i ocena jego wpływu na handel staje się bardzo trudna. W analizie wykorzystuje się zmienne zero-jedynkowe (dummy variables), a zatem stwierdzenie, czy w przypadku danego produktu/sektora zostały zastosowane środki protekcjonistyczne, czy też nie [McDonald, Henn, 2011, s. 4].

Monitoring środków polityki handlowej stosowanych od czasu kryzysu wprowadzono w Światowej Organizacji Handlu, która gromadzi dane dotyczące stosowanych instrumentów ograniczających handel, ale także instrumentów liberalizujących obroty. Do środków ograniczających handel zalicza się nowe taryfy celne, podniesienie dotychczasowych stawek celnych, a także wprowadzenie zakazów importu lub ograniczeń ilościowych, bardziej złożonych regulacji i procedur celnych czy przepisów domieszkowych (wymogów składnika krajowego - local 
content requirements) [WTO, 2017b, s. 74]. Do października 2017 r. monitorowane kraje WTO wprowadziły ponad 1730 tego typu instrumentów [WTO, 2017a, s. 27]. Część z nich to narzędzia o charakterze tymczasowym, ale ciągle w mocy pozostaje ponad 75\% zastosowanych środków [Kommerskollegium, 2016, s. 15]. Jednocześnie eksperci Światowej Organizacji Handlu analizują instrumenty, których celem jest liberalizacja handlu. Jak wynika z danych przedstawionych na rysunku 2, liczba zastosowanych środków liberalizujących przewyższała liczbę wprowadzonych barier we wszystkich analizowanych latach z wyjątkiem lat 2009 i 2013. Do najczęściej stosowanych środków liberalizujących handel należały obniżki stawek celnych. Takie podejście nie pozwala jednak ocenić znaczenia zastosowanych instrumentów z jednej czy drugiej grupy i określenia, które instrumenty w większym stopniu wpływają na poziom obrotów handlowych.

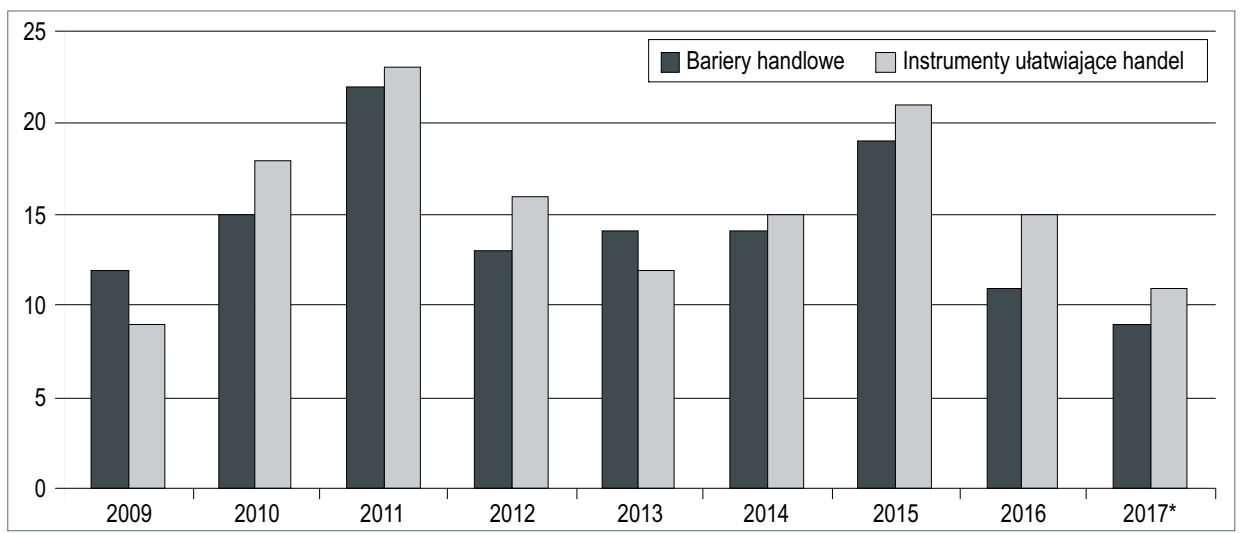

* Dane obejmują okres od połowy października 2016 r. do połowy października $2017 \mathrm{r}$.

Rysunek 2. Liczba środków ograniczających handel i narzędzi liberalizujących handel stosowanych przez monitorowane kraje członkowskie WTO w latach 2009-2017 (średnio na miesiąc)

Źródło: [WTO, 2017a; WTO, 2017b].

Zdecydowanie większą liczbę protekcjonistycznych decyzji rządów od czasu kryzysu uwzględnia baza Global Trade Alert (GTA). Projekt zapoczątkowano w czerwcu 2009 r. w celu gromadzenia informacji na temat instrumentów wpływających na handel. Obejmuje on 233 kraje, choć publikowane raporty koncentrują się przede wszystkim na grupie G20. Dotychczas opublikowano 21 raportów, a baza interwencji krajów w handel obejmuje 13672 pozycji (rys. 3). Interwencje podzielono na trzy grupy, z których tzw. grupa czerwona i żółta zawierają bariery handlowe. Do grupy czerwonej zaliczono instrumenty, które zostały wprowadzone i negatywnie wpływają na handel, a do żółtej te, które mogą mieć na niego negatywny wpływ lub zostały ogłoszone, ale nie weszły w życie. 
Grupa zielona to instrumenty przyczyniające się do liberalizacji handlu. Do tej grupy należało jedynie $26 \%$ wszystkich zamieszczonych w bazie decyzji rządów.

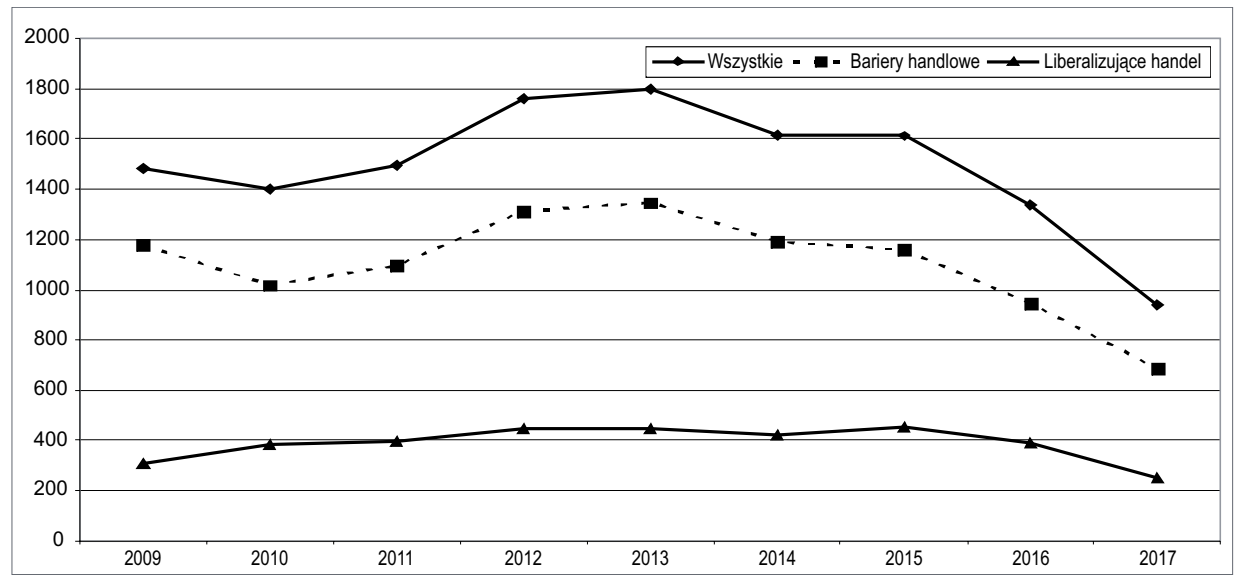

Rysunek 3. Liczba zastosowanych środków ograniczających handel i narzędzi liberalizujących handel w latach 2009-2017 według Global Trade Alert

Źródło: [GTA, 2017].

W tabeli 1 zaprezentowano 10 krajów, które w analizowanym okresie najczęściej wprowadzały bariery handlowe. Na początku zestawienia znalazły się Stany Zjednoczone, zdecydowanie przewyższając pozostałe kraje pod względem liczby zastosowanych instrumentów. Drugą pozycję zajmują Niemcy, które jeszcze w połowie $2017 \mathrm{r}$. zajmowały pozycję piątą, ale tylko w ciągu drugiej połowy $2017 \mathrm{r}$. zdążyły wyprzedzić Indie, Rosję i Argentynę. W tym samym okresie do pierwszej dziesiątki z 12 pozycji awansowały Chiny. Warto także zauważyć, że w ostatnim okresie w całkowitej liczbie wprowadzanych przez kraje G20 barier handlowych wzrasta udział krajów G7 i Australii. Według ostatniego raportu GTA wynosił on $53,9 \%$, podczas gdy kraje BRICS odpowiadały jedynie za $26,3 \%$ protekcjonistycznych instrumentów. W 2009 r. wskaźniki te były bardziej zbliżone i wynosiły odpowiednio 40,5\% i 37,1\% [Evenett, Fritz, 2017, s. 38].

Na pierwszym miejscu wśród krajów, wobec których stosowano instrumenty o charakterze protekcjonistycznym, znalazły się Chiny. Kolejne pozycje zajmowały kraje UE - Niemcy, Włochy i Francja, a na miejscu piątym znalazły się Stany Zjednoczone (tab. 1).

Jeśli chodzi o branże, wobec których najczęściej stosowano ograniczenia, to należały do nich: przemysł metalowy, zwłaszcza produkty z żelaza i stali, maszynowy, motoryzacyjny, energetyczny (energia elektryczna), chemiczny (chemia organiczna) oraz rolnictwo [Evenett, Fritz, 2017, s. 42]. 
Tabela 1. Kraje, które wprowadziły najwięcej barier, i kraje, wobec których najczęściej stosowano bariery handlowe w okresie 2009-2017 według Global Trade Alert (liczba wprowadzonych środków)

\begin{tabular}{|l|c|l|c|}
\hline \multicolumn{2}{|c|}{ Kraje stosujące bariery } & \multicolumn{2}{c|}{ Kraje, wobec których stosowano bariery } \\
\hline \multicolumn{1}{|c|}{ kraj } & liczba środków & \multicolumn{1}{c|}{ kraj } & liczba środków \\
\hline Stany Zjednoczone & 1376 & Chiny & 4531 \\
\hline Niemcy & 850 & Niemcy & 3930 \\
\hline Indie & 789 & Włochy & 3593 \\
\hline Rosja & 595 & Francja & 3520 \\
\hline Argentyna & 517 & Stany Zjednoczone & 3246 \\
\hline Brazylia & 464 & Wielka Brytania & 3188 \\
\hline Japonia & 398 & Japonia & 3033 \\
\hline Wielka Brytania & 397 & Korea Płd. & 2989 \\
\hline Włochy & 339 & Kanada & 2952 \\
\hline Chiny & 309 & Hiszpania & 2912 \\
\hline
\end{tabular}

Źródło: [GTA, 2017].

Dane dotyczące liczby zastosowanych instrumentów pokazują, że rosło zainteresowanie narzędziami ograniczającymi handel, nie tylko bezpośrednio po kryzysie, ale także w późniejszych latach. Oszacowanie wpływu zastosowanych instrumentów na obroty handlowe jest trudne. Analizy przeprowadzone przez ekspertów Międzynarodowego Funduszu Walutowego, dotyczące środków wprowadzonych bezpośrednio po kryzysie (dane do kwietnia 2010 r.), pokazały, że na poziomie produktów zastosowanie wyższych stawek celnych powodowało spadek obrotów o 5\%, natomiast instrumentów typu behind-the-border - o 7\% . Jednak na poziomie zagregowanym wpływ na globalny handel, wynoszący $0,2 \%$ rocznie, oceniono jako niewielki [McDonald, Henn, 2011, s. 35]. Simon Evenett i Johannes Fritz ocenili, że protekcjonizm miał duży wpływ na niższe tempo wzrostu handlu, zwłaszcza w najsłabiej rozwiniętych krajach [Evenett, Fritz, 2015a] i w przypadku określonych branż (przemysł stalowy) [Evenett, Fritz, 2015b]. Podkreślają oni także, że coraz większe znaczenie mają instrumenty, które polegają na subsydiowaniu krajowych przedsiębiorstw.

\section{Protekcjonizm taryfowy}

Początek XXI w. charakteryzował się systematyczną liberalizacją handlu, zwłaszcza w odniesieniu do stawek celnych. W krajach rozwiniętych średnia stawka celna w latach 2000-2007 spadła z 4,34\% do 3,75\%, a w krajach rozwijających się z 14,51\% do 10,55\% (tab. 2). Po roku 2008 proces liberalizacji został 


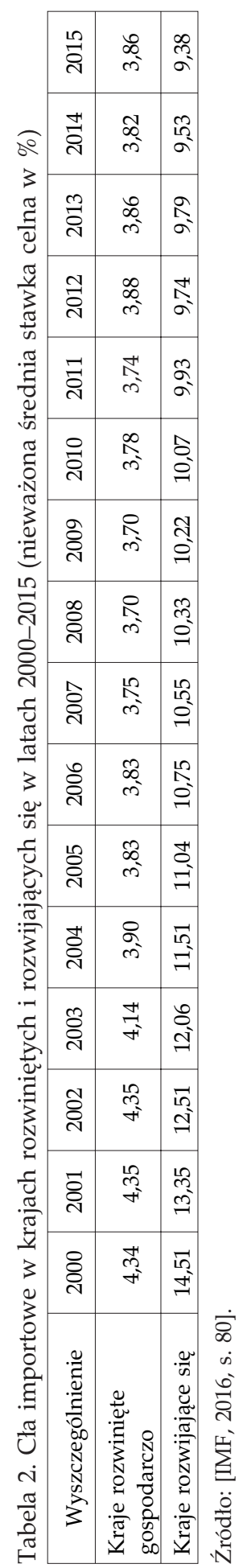


zahamowany. W latach 2008-2015 cła w krajach rozwijających się spadły o około 1 p.p. W przypadku krajów rozwiniętych gospodarczo cła nieznacznie wzrosły do $3,86 \%$ w 2015 r.

Analizy stawek celnych bezpośrednio po kryzysie pokazują, że wzrost protekcjonizmu taryfowego w związku z kryzysem nie był powszechny. Jedynie kilka krajów (Rosja, Argentyna, Turcja, Chiny) podniosło cła na produkty mające duże znaczenie w imporcie. Unia Europejska czy Stany Zjednoczone chętniej wykorzystywały postępowania antydumpingowe [Kee, Neagu, Nicita, 2013, s. 342-346]. Dane za okres 2009-2016 dla krajów grupy G20 także pokazują, że wpływ stawek celnych jako formy ochrony rynku nie był znaczący - decyzje dotyczące obniżania stawek celnych przeważały nad podnoszeniem ceł. Średnio, wyższe stawki celne w tym okresie dotyczyły importu o wartości 100 mld USD rocznie z wyjątkiem lat 2009 i 2015 [Evenett, Fritz, 2017, s. 68]. Według danych GTA podwyższanie stawek celnych stanowiło jedynie 16,2\% liczby wszystkich barier handlowych nakładanych w okresie 2009-2017 (rys. 4).

\section{Protekcjonizm pozataryfowy}

Wraz z postępującą od zakończenia II wojny światowej liberalizacją ceł rosło znaczenie barier pozataryfowych, które zwłaszcza w okresach recesji i kryzysów dawały krajom możliwość ochrony krajowych producentów przy jednoczesnym pozostawaniu $\mathrm{w}$ zgodzie $\mathrm{z}$ międzynarodowymi zobowiązaniami dotyczącymi związania stawek celnych. Zmiany dotyczyły także kategorii stosowanych instrumentów pozataryfowych. Stopniowo ograniczano stosowanie instrumentów tradycyjnej polityki handlowej, takich jak ograniczenia ilościowe czy opłaty nakładane na import. Coraz większe znaczenie miały z kolei instrumenty nowego typu, mające charakter wewnętrznych regulacji (behind-the-border measures), w szczególności różnego rodzaju bariery techniczne [Wojtas, 2015b, s. 262].

Według danych Global Trade Alert po kryzysie najczęściej wykorzystywano takie instrumenty, jak rozmaite dyskryminacyjne subsydia (bezpośrednie i pośrednie), które stanowiły ponad 40\% wszystkich stosowanych barier handlowych (rys. 4). Należą do nich różne formy pomocy publicznej dla przedsiębiorców, a przede wszystkim: subsydia krajowe i pakiety ratunkowe, wsparcie związane z finansowaniem handlu oraz subsydia eksportowe [Kommerskollegium, 2016, s. 24-25].

Drugą grupą instrumentów pozataryfowych były środki ochronne (trade defence), do których zaliczono procedury antydumpingowe, cła wyrównawcze oraz tzw. klauzule ochronne (safeguards). Najchętniej wykorzystywanym instrumentem z tej grupy były procedury antydumpingowe [Kommerskollegium, 2016, s. 21]. 


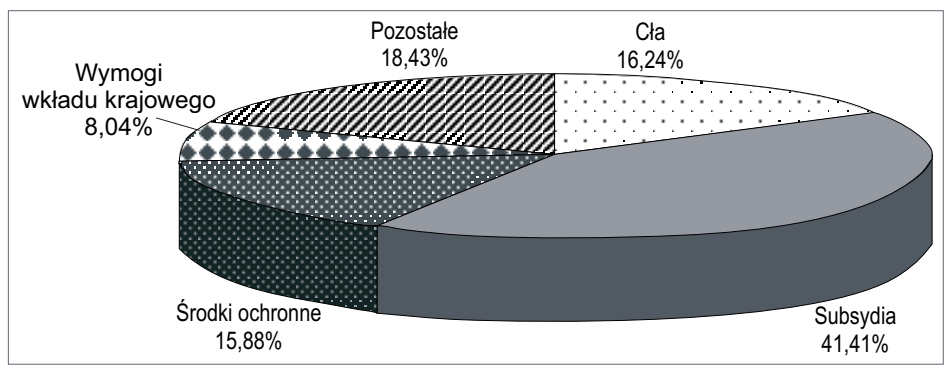

Rysunek 4. Kategorie barier handlowych stosowanych w latach 2009-2017 według Global Trade Alert

Źródło: [GTA, 2017].

Trzecią grupę instrumentów stanowiły różne formy obowiązku zastosowania krajowych składników (localization requirements). Istotą tych instrumentów jest zmuszenie producentów do pozyskiwania zasobów krajowych, nawet jeśli bardziej efektywne byłoby pozyskanie ich za granicą. Może to polegać na konieczności zakupu towarów lub materiałów krajowych i świadczenia usług przy wykorzystaniu krajowej infrastruktury, a także wymogu dokonania transferu technologii lub własności intelektualnej jako warunku dostępu do rynku czy obowiązku przechowywania danych w kraju. Często także możliwość uzyskania subsydiów $\mathrm{i}$ innych form wsparcia publicznego jest uwarunkowana koniecznością wykorzystania krajowych dóbr, usług czy własności intelektualnej [Kommerskollegium, 2016, s. 27-28]. Celem polityki Buy National jest wsparcie krajowych przedsiębiorstw i zatrudnienia, a także wzmocnienie mnożnikowych efektów pakietów fiskalnych. Tymczasem okazuje się, że korzyści z tytułu zwykłych wydatków rządowych są większe niż w przypadku powiązania ich z polityką Buy National [Larch, Lechthaler, 2011]. Klauzulę „Buy American” zawierał np. pakiet stymulacyjny wprowadzony w 2009 r. w Stanach Zjednoczonych. Analiza przeprowadzona przez ekspertów OECD na podstawie instrumentów wprowadzonych w latach 2008-2014 pokazała, że mimo krótkoterminowych pozytywnych efektów w postaci wzrostu zatrudnienia przyczyniły się one do obniżenia obrotów handlowych i PKB stosujących je krajów [Stone, Messent, Flaig, 2015, s. 70].

\section{Postępy w multilateralnej i regionalnej liberalizacji handlu}

Za przejaw protekcjonistycznych tendencji w gospodarce światowej można także uznać zahamowanie procesu liberalizacji polityki handlowej zarówno o zasięgu multilateralnym, jak i regionalnym. Rozpoczęta w 2001 r. kolejna runda wielostronnych negocjacji handlowych prowadzonych na forum Światowej 
Organizacji Handlu (tzw. Runda Doha) miała przynieść znaczące rozszerzenie zakresu dziedzin będących przedmiotem multilateralnych zasad handlu. Należały do nich, oprócz handlu towarami i produktami rolnymi, także usługi, inwestycje, prawa własności intelektualnej, polityka konkurencji czy ochrona środowiska. Szybko się okazało, że tak szeroko zakrojone negocjacje nie zostaną zakończone $w$ ciągu planowanych trzech lat. Przedłużające się rozmowy załamały się w związku z wybuchem kryzysu. W tamtym okresie ważniejsze było przeciwdziałanie jego skutkom i rokowania utknęły w martwym punkcie mimo powtarzających się deklaracji poszczególnych krajów oraz na szczytach G20 o chęci jak najszybszego ich zakończenia. Ożywienie rozmów nastąpiło pod koniec 2012 r., a jego efektem było podpisanie w czasie Konferencji Ministerialnych Światowej Organizacji Handlu na Bali (2013) oraz w Nairobi (2015) porozumień zawierających wynegocjowane rozwiązania dotyczące dalszej liberalizacji handlu. Trudno jednak uznać je za sukces, ponieważ zawierały one jedynie drobną część programu roboczego Rundy Doha, natomiast w przypadku kluczowych obszarów negocjacyjnych postępu nie zanotowano [Wojtas, 2016].

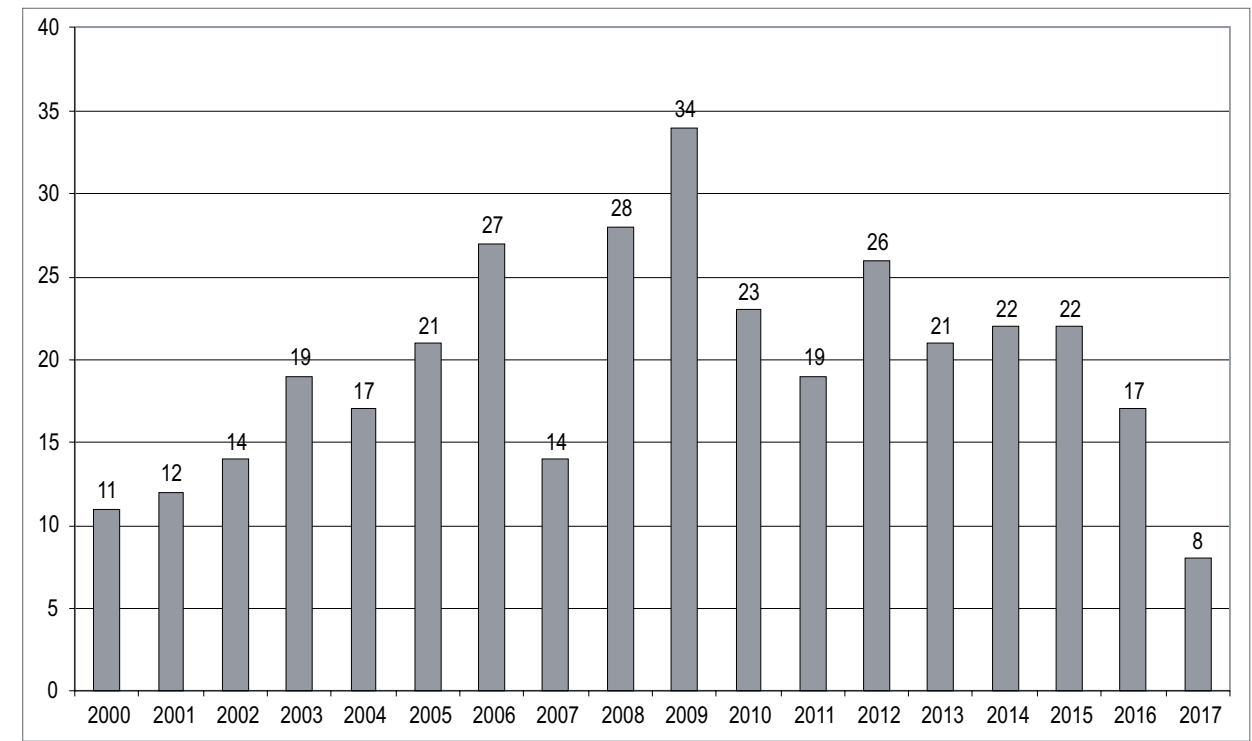

Rysunek 5. Liczba notyfikacji do WTO regionalnych porozumień handlowych w latach 2000-2017 według daty wejścia $\mathrm{w}$ życie porozumienia Źródło: [WTO, 2018].

Odpowiedź na problemy w multilateralnych rokowaniach handlowych stanowiła regionalizacja, która przejawiała się w podpisywaniu bilateralnych i kilkustronnych porozumien handlowych. Ich liczba rosła od połowy lat dziewięćdzie- 
siątych XX w., a zwłaszcza od początku XXI w. Kraje podpisujące umowy otrzymywały dostęp do nowych rynków zbytu, ale także zyskiwały sojuszników w negocjacjach Rundy Doha [Mucha-Leszko, 2014]. Nawet najbardziej zagorzali zwolennicy multilateralizmu (jak Unia Europejska czy Japonia) podejmowali rozmowy i podpisywali porozumienia [Pasierbiak, 2016, s. 67]. Układy handlowe zaczęły wykraczać poza granice regionów i podjęto prace nad utworzeniem tzw. porozumień międzyregionalnych, nazwanych także megaregionalnymi (mega-regionals). Są to układy negocjowane przez co najmniej trzy kraje (ugrupowania) odpowiadające za co najmniej 25\% światowego handlu [Draper, Lacey, Ramkolowan, 2014, s. 8]. Do najważniejszych porozumień tego typu należy Partnerstwo Transpacyficzne (Trans-Pacific Partnership - TPP) oraz Transatlantyckie Partnerstwo w dziedzinie Handlu i Inwestycji (Transatlantic Trade and Investment Partnership - TTIP). TPP obejmuje negocjacje 12 państw z Ameryki Północnej (NAFTA), Ameryki Południowej oraz Azji i Pacyfiku, a TTIP to rokowania między Unią Europejską a Stanami Zjednoczonymi [Wojtas, 2015a, s. 398].

Od czasu kryzysu można zaobserwować stopniowy spadek liczby tego typu porozumień notyfikowanych do Światowej Organizacji Handlu (rys. 5), należy jednak zaznaczyć, że zakres nowo podpisywanych umów staje się coraz szerszy i wykracza poza liberalizację handlu towarami. Niestety w przypadku wielu porozumień będących w trakcie negocjacji postępy wyraźnie zostały zahamowane. Jedna z pierwszych decyzji nowo wybranego prezydenta Donalda Trumpa dotyczyła wycofania się Stanów Zjednoczonych z rozmów na temat Partnerstwa Transpacyficznego [Narine, 2017, s. 2], a jednym z haseł wyborczych jego kampanii było wycofanie Stanów Zjednoczonych także z Północnoamerykańskiej Strefy Wolnego Handlu (NAFTA).

\section{Podsumowanie}

Kryzys gospodarczy lat 2008-2009 wywołał obawy dotyczące rozprzestrzeniania się polityki protekcjonizmu i eskalacji barier handlowych, których skutkiem byłby spadek globalnych obrotów handlowych. Stąd szybko pojawiły się narzędzia monitorowania sytuacji, a najważniejsi uczestnicy handlu deklarowali poparcie dla liberalizacji handlu (G20). W efekcie, w pierwszych latach po kryzysie gwałtowny wzrost protekcjonizmu nie nastąpił, a wpływ wprowadzanych działań oceniono jako nieznaczny. Może to także wynikać ze stosowania tzw. mętnych form protekcjonizmu (murky protectionism), które nie pozwalają na w pełni skuteczne monitorowanie i mierzenie ich dotkliwości. Przedstawione w pracy dane pokazują wzrost znaczenia barier o charakterze regulacyjnym, wynikających z wewnętrznych przepisów poszczególnych krajów, nie zawsze 
wprowadzanych w celu ograniczenie handlu, ale często powodujących takie skutki. Najpopularniejszymi instrumentami stosowanymi w analizowanym okresie 2009-2017 były różnego typu formy subsydiowania przedsiębiorstw.

Niepokojący wydaje się fakt, że liczba nowych narzędzi wzrasta, co więcej, można zaobserwować, że zwłaszcza te wprowadzane od 2015 r. dotyczą coraz większej części produktów będących przedmiotem obrotów międzynarodowych. Zdecydowany zwrot w kierunku polityki protekcjonizmu nastąpił w Stanach Zjednoczonych od czasu objęcia urzędu prezydenta przez Donalda Trumpa. Już w kwietniu 2017 r. podniesione zostały stawki celne na drewno importowane z Kanady, a przewiduje się podjęcie szeregu kolejnych działań o charakterze protekcjonistycznym [Bown, 2017].

Ważnym czynnikiem wpływającym na decyzje dotyczące zaangażowania się przedsiębiorców w handel z zagranicą jest niepewność co do przyszłej polityki handlowej. Sytuacja gospodarcza, ale także zmiany w polityce handlowej krajów (USA) czy negocjacje w sprawie wystąpienia Wielkiej Brytanii z Unii Europejskiej wywołują wątpliwości co do przyszłych warunków handlu [Jean, 2017]. To z kolei, według ostatnich wyników badań, ogranicza decyzje o wchodzeniu na zagraniczne rynki [Crowley, Song, Meng, 2016; Handley, Limao, 2016].

Skutki działań protekcjonistycznych mogą być dotkliwe dla światowej gospodarki [Genereux, 2017]. Efektem jest np. wzrost kosztów importu, który odbija się negatywnie na wzroście produktywności, przyczynia się do wzrostu cen, może prowadzić do wojen handlowych, niekoniecznie jednak doprowadzi do poprawy salda bilansu handlowego, co jest ważnym motywem polityki handlowej prowadzonej przez amerykański rząd.

\section{Bibliografia}

Białowąs T., 2017, Główne czynniki spadku dynamiki handlu międzynarodowego w latach 2008-2015, International Business and Global Economy, nr 36.

Bown Ch., 2017, Steel, Aluminum, Lumber, Solar. Trump's Stealth Trade Protection, Peterson Institute Policy Brief, PB17-21.

Constantinescu C., Mattoo A., Ruta M., 2015, The Global Trade Slowdown. Cyclical or Structural?, Policy Research Working Paper, no. 7158, World Bank Group, Washington, D.C.

Crowley M., Song H., Meng N., 2016, Tariff Scares. Trade policy uncertainty and foreign market entry by Chinese firms, CEPR Discussion Paper, no. 11722.

Draper P., Lacey S., Ramkolowan Y., 2014, Mega-Regional Trade Agreements. Implications for the African, Caribbean, and Pacific countries, ECIPE Occasional Paper, no. 2.

$\mathrm{ECB}, 2016$, Understanding the weakness in global trade. What is the new normal?, European Central Bank Occasional Paper Series, no. 178.

Eichengreen B., 2008, Should we fear a trade backlash?, The Guardian, 31 December, https://www.theguardian.com/commentisfree/2008/dec/31/trade-policy-tariffs-us-uk [dostęp: 15.01.2018]. 
Evenett S., Fritz J., 2015a, Crisis-era trade distortions cut LDC export growth by 5.5\% per annum, [w:] The Global Trade Slowdown. A New Normal?, ed. B. Hoekman, VoxEU ebook, CEPR Press.

Evenett S., Fritz J., 2015b, 'Peak trade' in the steel sector, [w:] The Global Trade Slowdown. A New Normal?, ed. B. Hoekman, VoxEU, CEPR Press.

Evenett S., Fritz J. (eds.), 2017, Will Awe Trump Rules? The 21st GTA Report, CEPR Press.

Genereux F., 2017, Protectionism. A brake on economic growth, Desjardins Economic Studies, February 17.

GTA, 2017, Global Trade Alert, http://www.globaltradealert.org/data-exports [dostęp: 10.02.2018].

Handley K., Limao N., 2016, Policy uncertainty, trade and welfare. Theory and evidence for China and the U.S., NBER Working Paper, no. 19376.

Hoekman B. (ed.), 2015, The Global Trade Slowdown. A New Normal?, VoxEU, CEPR Press.

IMF, 2016, World Economic Outlook. Subdued Demand - Symptoms and Remedies, October.

Jean S., 2017, The Slowing in World Trade. A Structural Break, the Cause of Uncertainty, Foundation Robert Schuman European Issue, no. 421.

Kee H., Neagu Ch., Nicita A., 2013, Is Protectionism on the Rise? Assessing National Trade Policies during the Crisis of 2008, The Review of Economics and Statistics, vol. 95, no. 1.

Kommerskollegium, 2016, Protectionism in the 21st Century, National Board of Trade, Stockholm.

Larch M., Lechthaler W., 2011, "Buy National" and protectionism in the great recession. Can it work?, Intereconomics, vol. 46, no. 4.

McDonald B., Henn Ch., 2011, Protectionist Responses to the Crisis. Damage Observed in Product-Level Trade, IMF Working Papers, no. 11/139.

Mucha-Leszko B., 2014, Globalna czy regionalna liberalizacja handlu międzynarodowego?, Zeszyty Naukowe Uniwersytetu Szczecińskiego. Współczesne Problemy Ekonomiczne. Globalizacja. Liberalizacja. Etyka, nr 8.

Narine S., 2017, The End of the TPP. Symptoms of American Decline and ASEAN's Response, ISEAS, no. 25.

Ollivaud P., Schwellnus C., 2015, Does the Post-Crisis Weakness of Global Trade Solely Reflect Weak Demand?, OECD Economics Department Working Papers, no. 1216, OECD Publishing, Paris.

Pasierbiak P., 2016, Shift in Japanese Policy towards Preferential Trade Agreements and its Impact on Foreign Merchandise Trade, Contemporary Issues in Business and Government, vol. 22 , no. 1.

Stone, S., Messent J., Flaig D., 2015, Emerging Policy Issues. Localisation Barriers to Trade, OECD Trade Policy Papers, no. 180, OECD Publishing, Paris.

UNCTAD, 2018, UNCTADStat Database, http://unctadstat.unctad.org [dostęp: 03.02.2018].

Wojtas M., 2015a, Międzynarodowa polityka handlowa w XXI wieku - główne trendy, Studia i Prace Wydziału Nauk Ekonomicznych i Zarządzania Uniwersytetu Szczecińskiego, t. 1 , nr 41.

Wojtas M., 2015b, Wzrost znaczenia barier pozataryfowych w polityce handlowej, Annales Universitatis Mariae Curie-Skłodowska, Sectio H, Oeconomia, vol. 49, no. 2.

Wojtas M., 2016, Negocjacje Rundy Doha - postępy w czasie Konferencji Ministerialnych w Bali i Nairobi, Finanse, Rynki Finansowe, Ubezpieczenia, nr 3. 
Wojtas M., 2017, Przyczyny spowolnienia światowego handlu, Studia i Prace Wydziału Nauk Ekonomicznych i Zarządzania Uniwersytetu Szczecińskiego, t. 2, nr 49.

WTO, 2017a, Report to the TPRB from The Director-General on trade-related developments, WT/TPR/OV/W/11.

WTO, 2017b, World Trade Statistical Review 2017.

WTO, 2018, http://rtais.wto.org [dostęp: 10.02.2018].

M. Wojtas (-) monika.wojtas@poczta.umcs.lublin.pl

Katedra Gospodarki Światowej i Integracji Europejskiej, Wydział Ekonomiczny, Uniwersytet Marii Curie-Skłodowskiej w Lublinie, pl. M. Curie-Skłodowskiej 5, 20-31 Lublin, Polska 